\title{
Occurrence of Fasciola gigantica and Paramphistomum spp Infection in Aceh Cattle
}

\author{
Muhammad Hambal $^{1 *}$, Rizka Ayuni ${ }^{1}$, Henni Vanda $^{2}$, Amiruddin Amiruddin ${ }^{3}$, and Farida Athaillah ${ }^{1}$ \\ ${ }^{1}$ Laboratory of Parasitology, Faculty of Veterinary Medicine, Universitas Syiah Kuala, Indonesia \\ ${ }^{2}$ Laboratory of Pharmacology, Faculty of Veterinary Medicine, Universitas Syiah Kuala, Indonesia \\ ${ }^{3}$ Laboratory of Clinic, Faculty of Veterinary Medicine, Universitas Syiah Kuala, Indonesia
}

\begin{abstract}
Fasciola gigantica and Paramphistomum spp. are trematode helminth causing severe economic losses in cattle farming in Aceh Province, Indonesia. This study was conducted to examine the correlation between the prevalence of $F$. gigantica and Paramphistomum spp infections with the body condition and sex of Aceh cattle. In total, 103 cattle (50 males and 53 females) from an abattoir in Banda Aceh were used. The body condition score was recorded and the number of fluke eggs in feces was examined coproscopically. The results showed that $F$. gigantica prevalence was $41 \%$ and $72 \%$ in females and males, respectively, whereas, the prevalence of Paramphistomum spp in females and males was $81 \%$ and $72 \%$, respectively. The average number of fasciola eggs was 2.55 eggs/ g feces and 2.75 eggs/ g feces in females and males, respectively, The average number of Paramphistomum spp eggs was 127.6 eggs/g feces and 36.8 eggs/ $\mathrm{g}$ feces in males, and female respectively. Based on the Body Condition Score (BCS), the prevalence of both trematodes was higher in the skinny cattle (BSC 2 and 3). This study established that the infection of Fasciola in BCS 3 was higher than BCS 2 and 4. Male cattle were more susceptible to infection than females.
\end{abstract}

Keywords: epidemiology, sex influence, Body condition score, F. gigantica, Paramphistomum spp.

\section{Introduction}

Fasciola gigantica and Paramphistomum spp. are the common trematode helminth infesting cattle and other ruminants worldwide [1-3]. These worms cause severe economic losses in cattle farming due to weight loss, reduced milk production, low fertility rates, and in some cases death [4-5]. Several previous studies reported high morbidity and mortality in young and adult cattle due to these parasitic outbreaks [6-7], delayed growth, anemia, tissue damage, especially in liver and bile ducts, and reduction in productivity $[1,8]$. The economic loss in Indonesia due to the infestation of $F$. gigantica and Paramphistomum spp. is more than USD $=\$ 3.2$ billion annually [9].

In general, cattle are infected by trematode when they swallow metacercariae attached to the grass and water [10-11]. Moreover, the density of metacercariae is influenced by the population size of snails Bulinus spp. and Planorbis spp. as the intermediate hosts. The prevalence of paramphistomiasis and fasciolosis relates to several factors, among them the grazing system [12-13], nutrition status, climate, ecosystem, and genetic aspects [14]. According to Putra et al. [13], pasture quality influenced the number of infected animals by trematode, F. gigantica, and Paramphistomum spp. In cattle fed with forage, the prevalence rate reached $30 \%$, but the value decreased to $6 \%$ - $19 \%$ when the cattle fed on concentrate feed. In Indonesia, rice cultivation is part of the culture, and the paddy fields are important habitat for Fasciola and Paramphistomum metacercariae, a source infection of this trematode. A special case where trematode prevalence rates reached $90 \%$ on cattle grazing freely in paddy fields has been reported [15].

A lot of previous studies focused on the infestation of the $F$. gigantica and Paramphistomum spp. in ruminants [2, 18-19]. Nevertheless, no study has evaluated the correlation between body condition score (BCS) and trematode infection in Aceh cattle. The BCS is an important practical method of assessing the body condition of the livestock since it is a simple indicator of fat reserves in the body [20]. The information about the correlation between BCS and parasitic disease status is also essential for livestock management decision making. Moreover, the influence of sex on the prevalence and egg number of the F. gigantica and Paramphistomum spp infestation in Aceh cattle has not been studied previously. This information is essential in preventing the disease caused by the aforementioned parasites. For this reason, this study was conducted to examine the effect of sex and body condition score on the prevalence of the $F$. gigantica and Paramphistomum spp. in Aceh cattle.

*Corresponding author: hambal.m@unsyiah.ac.id 


\section{Materials and Methods}

\subsection{Collection of parasites}

A total of 103 Aceh cattle, consisting of 50 males and 53 females from a slaughterhouse in Banda Aceh City were selected to be examined for fasciolosis and paramphistomosis prevalence rate, body condition score (BCS) and intensity of trematode infection. The feces were collected from rectum coproscopically and put into a transparent plastic bag. All samples were labeled and stored in a cooling container at a temperature of $5{ }^{\circ} \mathrm{C}$ before the examination.

\subsection{Measurement of body condition score (BCS)}

The BCS is a parameter used to analyze the body condition of an animal unit. In this study, it was carried out through observation and palpation on the body fat deposits under the skin around the base of the tail, spine, and hip. Assessment of the body condition was performed visually and by palpation of fat deposits in cattle body parts such as at the hind and quarter of the back, the processus spinosus, processus spinosus to processus transversus, tuber coxae (hooks) between the coxae tuber and the ischiadicus tuber, the right and left tuber coxae, and the base of the tail to the ischiadicus tuber [21]. The score ranges from $1-5$, where score 1 = very thin, 2 = lean, $3=$ medium, $4=$ fat and $5=$ very fat.

\subsection{Examination of worm eggs}

The modification of sedimentation method was used in this study (15). A total of three grams of feces were weighed and put into the mortar and diluted with $20 \mathrm{ml}$ of water. The solution of Tween- 80 was added and then homogenized by a magnetic stirrer for $5 \mathrm{~min}$. The solution was filtered using mess 300 , and the filtered material was sprayed with water, refilled with $100 \mathrm{ml}$ of water and then left for three minutes before the removal of the supernatant. This procedure was repeated twice. The remaining sediment was further dropped with $1 \%$ Methylene blue to distinguish debris from trematode eggs and transferred into a petri dish that was given a line for orientation. The presence of Fasciola sp. eggs is characterized by golden yellow, while Paramphistomum spp is bluish-gray. The eggs were counted and recorded using a binocular microscope at $1000 \mathrm{X}$ magnification.

\subsection{Statistical analysis}

The data were subjected to the student T-test to analyze the effect of sex and body condition score on the worms' prevalence and egg number, while the Chi-squared test was used to compare the spread between males and females at a confidence limit of $5 \%$.

\section{Results and Discussion}

\subsection{Results}

The study showed that $28(27 \%)$ of the cattle were positively infected by $F$. gigantica and Paramphistomum spp and indicated a mixed infection of both parasites in Aceh cattle. Besides, 37 cattle had BCS 2, 47 had BCS 3 and 19 had BCS 4 (Table 1). Generally, there was a positive correlation between prevalence and BSC, where the pervasiveness of parasites increased with an increase in BCS. For example, the prevalence of Paramphistomum spp. at BCS 2 was $16 \%$, but increased to $55 \%$ and $94 \%$ at BCS 3 and BCS 4 respectively. The study also detected a mixed infection of $F$. gigantica and Paramphistomum spp. in Aceh cattle. The higher mixed infestation was found in cattle with BCS 3 followed by BCS 2 (Table 1).

The results of the stool examination showed the eggs of $F$. gigantica were golden yellow with a size of $180 \mu \mathrm{m}$ in length and $95 \mu \mathrm{m}$ width. The average number of eggs in males was 2.76 eggs gram- 1 feces and 2.56 eggs gram1 feces in females. The eggs of Paramphistomum spp. was transparent and showed clear embryonal cells. The egg size was 113-175 $\mu \mathrm{m}$ in length, and 73-100 $\mu \mathrm{m}$ width, and equipped with an operculum. The number of Paramphistomum eggs was 127.57 and 36.78 eggs gram1 feces in males and females, respectively. The student Ttest showed the sex of cattle gave a significant effect on prevalence and the number of eggs of the $F$. gigantica and Paramphistomum spp. $(\mathrm{P}<0.05)$.

The study showed the prevalence of $F$. gigantica in male cattle was higher than in females (Table 2). The contrary finding was found in Paramphistomum spp. In which the higher prevalence was recorded in female cattle (Table 2).

Tabel 1. Body condition score and trematode prevalence of 103 cattle

\begin{tabular}{lllll}
\hline BCS & Total & $\begin{array}{l}\text { F. gigantica } \\
\text { Prevalence }\end{array}$ & $\begin{array}{l}\text { Paramphistomum spp. } \\
\text { Prevalence }\end{array}$ & $\begin{array}{l}\text { F. gigantica }+ \\
\text { Paramphistomum spp. }\end{array}$ \\
\hline 5 & 0 & $0(0 \%)$ & $0(0 \%)$ & $0(0 \%)$ \\
4 & 19 & $4(21 \%)$ & $18(94 \%)$ & $3(16 \%)$ \\
3 & 47 & $17(36 \%)$ & $26(55 \%)$ & $15(32 \%)$ \\
2 & 37 & $4(11 \%)$ & $6(16 \%)$ & $10(27 \%)$ \\
1 & 0 & $0(0 \%)$ & $0(0 \%)$ & $0(0 \%)$ \\
\hline
\end{tabular}




\subsection{Discussion}

The study showed 25 and 50 cattle samples were infested by $F$. gigantica and Paramphistomum respectively, while the remaining 28 were infected by both parasites. The infestation of helminth in cattle is influenced by both internal and external factors. The external factors include age, sex, and breed, whilst intrinsic aspects include climate, environment, and farm management [22-23]. Animal age is one of the most important factors in fasciolosis, where the cattle older than 12 months are more susceptible to $F$. gigantica compared to younger ones [24].

Table 2. The number of eggs in feces and the prevalence of Fasciola gigantica in cattle

\begin{tabular}{llllll}
\hline Sex & Sample & Positive & $\begin{array}{l}\text { Total of } \\
\text { eggs }\end{array}$ & $\begin{array}{l}\text { Average eggs } \\
\text { gram feces }\end{array}$ & $\begin{array}{l}\text { Prevalence } \\
(\%)\end{array}$ \\
\hline Male & 50 & 36 & 99 & $2.75^{\mathrm{a}}$ & $72^{\mathrm{a}}$ \\
Female & 53 & 22 & 56 & $2.55^{\mathrm{a}}$ & $41^{\mathrm{b}}$ \\
\hline Total & 103 & 58 & 155 & 2.65 & 56.3 \\
\hline
\end{tabular}

${ }^{\mathrm{a}, \mathrm{b}}$ Different superscript in the same column showed a significant difference between male and female $(\mathrm{P}<0.05)$

Tabel 3. The average of eggs in feces and the prevalence of Paramphistomum spp. in cattle

\begin{tabular}{llllll}
\hline Sex & Sample & Positive & Total eggs & EpG & $\begin{array}{l}\text { Prevalence } \\
(\%)\end{array}$ \\
\hline Male & 50 & 36 & 4593 & $127.6^{\mathrm{a}}$ & $72^{\mathrm{a}}$ \\
Female & 53 & 43 & 1582 & $36.8^{\mathrm{b}}$ & $81^{\mathrm{b}}$ \\
\hline \multicolumn{7}{l}{ Total } & 103 & 79 & 2038 & 25.82 & 76.7 \\
\hline ifferent superscript in in the same column showed a significant difference between male and female $(\mathrm{P}<0.05)$ EpG $=$ egg per gram feces.
\end{tabular}

The prevalence of $F$. gigantica in this study was higher than in other reports in Indonesia and other tropical countries such as Borneo [25], West Java [26], Vietnam [27], and Iran [28].

Based on sex, the prevalence rate of $F$. gigantica in male cattle was significantly higher than in females. Therefore, it was assumed the female had a lower risk factor to $F$. gigantica infection. This finding is in agreement with [12], who examined the intensity of $F$. gigantica in cattle and established that the male's infection rate was higher than in females. This condition was attributed to the hormonal system where the estrogen triggers properties of Reticulo Endothelial System (RES) in cells mediated through direct chemical interaction with lymphoid and nonlymphoid tissue, resulting in the release of soluble immunoregulatory factors. These factors are produced by thymic epithelium in response to an estrogen stimulus. Furthermore, according to [25], the phagocytic activity of the RES in animals may be measured by the number of particles present in the blood. However, it is well-known that estrogen stimulates the level of RES in the animal body. This hormone induces the blood clearance rate and increases the number of phagocytes cells in the liver. By so doing, it enhances the immune system of the female cattle. Besides, the females are rarely used in plowing in the paddy field, especially in gravid condition, and therefore they have less contact with metacercariae, a source of infection. On the contrary, [30] reported a higher prevalence in females than in males in Bangladesh. This difference was attributed to the physiological conditions of female cattle during gravid and lactation. It may also be due to the lack of dietary supplements for production which leads to a decrease in the immunity of females. It is assumed that in malnutrition condition, estrogen interaction with RES is deactivated
The number of parasite eggs in feces showed the male cattle ( $2.75 \mathrm{eggs} / \mathrm{g}$ of feces) had a slightly higher number than females ( 2.55 eggs g- 1 of feces). The number of eggs of $F$. gigantica was higher than in a previous report by [26], who recorded 1.31 eggs/g feces in cattle in Borneo. According to [27], there were $49 \mathrm{eggs} / \mathrm{g}$ feces $(11.2 \%)$ in West Java. This is because Aceh Province is known to have a higher risk of $F$. gigantica infestation region in Indonesia [15, 31].

The study revealed that the BCS 3 dominated in all of the examined cattle. This indicated most of the cattle slaughtered in Banda Aceh municipal were quite lean. This finding was in agreement with [8], who reported that the level of intensity and prevalence of Paramphistomum spp. in ruminant of Ethiopia was higher in animals with poor body conditions. The study also showed the cattle sample with BCS 3 was the most infected by $F$. gigantica and Paramphistomum. This is, probably, related to age stage, an assertion supported by [15], where cattle with BCS 3 were mainly 2-4 years old, while 1.5 to 2.5 years old mostly had BCS 2 . The young cattle are generally free-roaming in a dry field and therefore most exposure to metacercariae. It was assumed that most of the young cattle do not have adequate antibody [32]. On the basis of body condition score, female cattle were more susceptible to $F$. gigantica infestation than the males. Besides, the weight loss in females was significantly higher than in males. This is in agreement with [33] who reported that female cattle in India were more susceptible to $F$. gigantica than the males. However, according to [34], F. gigantica leads to weight loss in goat (Capra hircus), though it did not specify the difference between males and females in response to the parasite. 


\section{Conclusion}

This study established that body condition score is linked with $F$. gigantica and Paramphistomum spp, infections. The parasites mostly infested the cattle with poor body conditions (BCS 2 and 3 ). The prevalence of $F$. gigantica was higher in males compared to females, whilst the incidence of Paramphistomum spp. was higher in females than males. In addition, the female cattle are more susceptibility to $F$. gigantica compared to the males.

\section{References}

1. Arias $\mathrm{M}$, Morrondo $\mathrm{P}$, Hillyer $\mathrm{GV}$, et al. : Immunodiagnosis of current fasciolosis in sheep naturally exposed to Fasciola hepatica by using a $\mathbf{2 . 9}$ kDa recombinant protein. Vet. Parasitol. 2007 ; 146: 4649.

2. Balqis U, Darmawi, S, Aisyah, et al. : . Perubahan patologi anatomi hati dan saluran empedu sapi aceh yang terinfeksi Fasciola gigantica. Agripet. 2013 ; 13: 53-58.

3. Khadijah S, Ariff Z, Nurlaili MR, et al: Fasciola and Paramphistomum infection in large ruminants. Int. $J$. Agro. Agric. Res., 2017 ;10: 19-26.

4. Admasu $P$ and Nurlign $L$ : Prevalence of gastrointestinal parasites of small ruminants in Kuarit District, North West Ethiopia. Afr. J. Bas. Appl. Sci. 2014 ; 6: 125-130.

5. Sukandar A, Purwanto BP., Anggraeni A : Keragaman Body Condition Score dan Produksi Susu Sapi Perah Friesian-Holstein di Peternakan Rakyat KPSBU Lembang, Bandung. 2008 ;Seminar nasional teknologi peternakan dan veteriner. Bandung.

6. Dube S. and Aisien MSO : Descriptive studies on Paramphistomes of small domestic ruminants in Southern Nigeria. ZJST. $2010 ;$ 5: 12-21.

7. Elelu N, Ambali A, Coles GC et al : and Eisler MC, Crosssectional study of Fasciola gigantica and other trematode infections of cattle in Edu Local Government Area, Kwara State, north-central Nigeria. Parasit vectors. $2016 ; 9: 470$.

8. Melaku S, and Addis M.: Prevalence and intensity of Paramphistomum in ruminants slaughtered at Debre Zeit Industrial Abattoir, Ethiopia. Glob Vet. 2012 ; 8:315-319.

9. Bekele M, Tesfay H, Getachew Y:Bovine Fasciolosis: Prevalence and Its Economic Loss Due to Liver Condemnation at Adwa Municipal Abattoir. 1, Ejast, North Ethiopia, 2010 ; 39-47

10. Keiser J, Veneziano V, Rinaldi L, et al : Anthelmintic activity of artesunate against Fasciola hepatica in naturally infected sheep. Res. Vet. Sci. 2010 ; 88: 107110.

11. Gordon CA, Acosta LP, Gobert GN, et al : High prevalence of Schistosoma japonicum and Fasciola gigantica in bovines from Northern Samar, the Philippines. PLoS Neglec. Trop. Dis. 2015; 9: e0003108.

12. Phiri AM, Phiri IK and Monrad J : Prevalence of amphistomiasis and its association with Fasciola gigantica infections in Zambian cattle from communal grazing areas. J. Helminth. 2006 ; 80: 65-68.

13. Putra DR, Suratman A. N, and Oka MBI : Prevalensi trematoda pada sapi bali yang dipelihara peternak di desa Sobangan, Kecamatan Mengwi, Kabupaten.
Bandung. Indonesia. Medicus Veterinus, 2014 ; 3: 394 402.

14. El-Tahawi AS, Bazh EK, and Khalafella RE : Epidemiology of bovine fascioliasis in the Nile delta region of Egypt: Its prevalence, evaluation of risk factors, and its economic significance. Vet World : 2017,10: 1241-1249.

15. Hambal M, Sayuti A, Dermawan A :. Tingkat Kerentanan Fasciola gigantica pada Sapi dan Kerbau di Kecamatan Lhoong, Kabupaten Aceh Besar. Jurnal Medika Veterinaria : 2013, 2: 25-29.

16. Yeneneh A, Kebede H, Fentahun, et al :Prevalence of cattle flukes infection at Andassa livestock research center in North-west of Ethiopia. Vet. Res. For ; 2012, 3:85-89.

17. El-Tahawi AS, Bazh EK. and Khalafella R :E Epidemiology of bovine fascioliasis in the Nile delta region of Egypt: Its prevalence, evaluation of risk factors, and its economic significance. Vet World, 2017,10: 1241-1249

18. Estuningsih SE : Diagnosa infeksi Fasciola gigantica pada sapi dengan uji Capture-ELISA untuk deteksi antigen dalam feses. JITV. 2006; 11: 229-234.

19. Nofyan E, Kamal M, and danRosdiana I : Identitas jenis telur cacing parasit usus pada ternak sapi (Bos sp) dan kerbau (Bubalus sp) di rumah potong hewan Palembang. Jurnal Penelitian Sains. 2010; 10: 6-11.

20. Alapati A, Kapa SR, Jeepalyam S, et al : Development of the body condition score system in Murrah buffaloes: validation through ultrasonic assessment of body fat reserves. J.Vet.Sci. $2010 ; 11: 1-8$.

21. Edmonson AJ, Lean IJ, Weaver LD, et al : A body condition scoring chart for Holstein dairy cows. Journal of Dairy Science 1989 ; 72: 68-70.

22. Lovera R, Fernández MS, Jacob J, et al : Intrinsic and extrinsic factors related to pathogen infection in wild small mammals in intensive milk cattle and swine production systems. PLoS neglected tropical diseases.2017; 11: 5722.

23. Yatswako $\mathrm{S}$ and Alhaji NB : Survey of bovine fasciolosis burdens in trade cattle slaughtered at abattoirs in north-Central Nigeria: the associated predisposing factors and economic implication. Parasit Epid. Control.2017; 2: 30-39.

24. Piedrafita D, Raadsma HW, Prowse Ret al : Immunology of the host-parasite relationship in fasciolosis (Fasciola hepatica and Fasciola gigantica). Canadian J. Zool.2004; 82: 233-250.

25. Ting L, Hoon C, Rong Z, et al: Quantitative Evaluation of the Reticuloendothelial System Function with Dynamic MRI. PLoS-one. 2014; 9, e103576

26. Tantri N, Setyawati TR, and Khotimah S :Prevalensi dan Intensitas Telur Cacing Parasit pada Feses Sapi (Bos Sp.) Rumah Potong Hewan (RPH) Kota Pontianak Kalimantan Barat. Protobiont. 2013; 2(2): 102-106.

27. Ananta SM, Hidayat A, and Matsubayashi M : Survey on gastrointestinal parasites and detection of Cryptosporidium spp. on cattle in West Java, Indonesia. Asian Pacific j. trop. Med. 2014; 7(3): 197201.

28. Nguyen TGT, Le TH, Dao THT, et al : Bovine fasciolosis in the human fasciolosis hyperendemic Binh Dinh province in central Vietnam. Acta. Trop. 2017; $117: 19-22$ 